\title{
Archaeology for Whose Interpretation?: \\ Finding Space for Alternative Archaeology in Indonesia
}

IRMAWATI MARWOTO-JOHAN

7 o date, archeological research has been widely conducted in Indonesia. The results of this research, however, are not widely known by the public because they are merely meant for archeologists. This leads the public to interpret archeological remains in their own neighborhoods. This public need of archeology could be promoted through archeological research being delivered to the public though exhibitions, museums or archeological sites.

This article presents a discussion of Indonesian archeologists' authority problems, the growths of Alternative Archeology as a 'challenge' to mainstream archeology and the implications Alternative Archeology has for the broader community. 


\section{ARCHEOLOGY AS AN AUTHORITY HOLDER}

Paul Ashton and Paula Hamilton describe history as a house with several rooms in which people from various groups, like history community, museum experts, history film makers, and so on, live together. Some historians claim that they live in the main parts of the house and that they are even the owners of the house. ${ }^{1}$ This can be applied to archeology where academic archeologists consider the heritage arena as belonging to them where their interpretations dominate.

It is generally believed that archeologists have the greatest authority to determine what constitutes heritage. Indeed, some believe that it is only archeologists who have the only authority to interpret archeological heritage. Is it wise to wait for an archeologist to interpret when a temple is found to get the best interpretation? After the Borobudur Temple was found, for example, its heritage value was just decided by archeologists.

Professional archeologists in Indonesia can be categorized into those in the governmental sectors, at universities and at research centers. These archeologists are considered to be the principal interpreters of archeological findings in Indonesia.

Museums previously believed to be object centers are at present becoming people-oriented institutions and play an important role in educating the public, instead of just accommodating archeologists' interests. ${ }^{2}$ Archeologists, therefore, have been urged to shift their old paradigm to be more publicly orientated due to their social responsibilities that the knowledge they have produced must be disseminated if only inasmuch as all archeological research is paid by the community. ${ }^{3}$

The question regarding this issue is, then, who has the authority to interpret heritage? The answer to this question is viewing archeology in Multi-vocal perspectives. Laurent Olivier argues that the archaeology of contemporary past not only deals with archaeological remains and that archeology cannot be reduced to an univocal study merely for archeologists. It should involve other fields from various disciplines such as politics to various cultural and political communities interested in heritage who can help shape new meanings and historical contexts in which they are involved. There are also other theoretical and ethical implications. Theoretical implications are connected to the reality that contemporary archeology confronts various meanings on ancient archeological remains. Ethical implications are closely connected to the idea that archeologists are not the only knowledge sources. ${ }^{4}$ 


\section{ALTERNATIVE ARCHEOLOGY}

Alternative Archeology can be defined as anything different from the facts archeology defines in reconstructing and describing the past. The term alternative archeology was originally used by Tim Schadla-Hall to refer to pseudo-scientific archaeology, fantastic archaeology, which differs from what is usually called main stream archaeology. Alternative archeology deserves the attention of traditional archeologists because this archeology challenges received archeological interpretations. ${ }^{5}$

Hiscock in his study of alternative archeology in Australia explains that it is generally known as Cult Archaeology. He argues that the pasts it constructs more factual than the interpretation conventional archeologists make. ${ }^{6}$

Alternative archeology has developed with complex and different perspectives. Tim Schadla-Hall, however, gives four types of explanation about the past that challenge conventional archeology:

1 Origins and hyper diffussionism, arguing that one origin for all civilizations and this spreads. For example, many experts in India say that ancient Indonesian culture came from India, or it is believed that a culture, generally called Atlantic culture, once sank in the west and another drowned in South-east Asia.

2 Ancient knowledge and power which perceives that the ancient society had greater knowledge and power than the present communities.

3 Astro-archeology: the main stream of alternative archaeology proposing an argument that there were intruders from the outer space who mastered the Earth in the past.

4 'Truths' of religion and mythology: archeological sites often connected to ancient religious activities, such as the worships to the ancients and to the proof of the truths of certain mythology.

\section{ALTERNATIVE ARCHEOLOGY IN INDONESIA}

Archeologists believe that Situs Trowulan in East Java was the capital city of the Majapahit Kingdom, and a lot of research has been conducted on this since the 1970s. However, for more than forty years, archeologists have not disseminated their research results into the community. These 
research results are just archeological excavations while archeological artifacts collected from these excavations are not quickly reported in the Trowulan museum. In 2008 and 2012 the research conducted by four universities in Indonesia to search for the center of the Majapahit Kingdom appeared to be able to identify the location of Majapahit Kingdom palace.

The failure of these archeologists to disseminate their research results to both the general public or the local people around Trowulan site has led to public confusion about their identity which is usually connected to Majapahit Kingdom. This was revealed when the focus group discussion was conducted by a research and development team from the Department of Tourism and Culture and the University of Indonesia in 2008. ${ }^{7}$

In its development in Indonesia, Alternative Archeology as the main focus in this article covers the four points proposed by Tim Schadla-Hall in which religious and mythological truths are foundations to interpret past archeological remains. This study centers on the Trowulan archeological site, in East Java, with three specific sites: Pendopo Agung, umur Upas and Siti Inggil.

\section{Pendopo Agung Site}

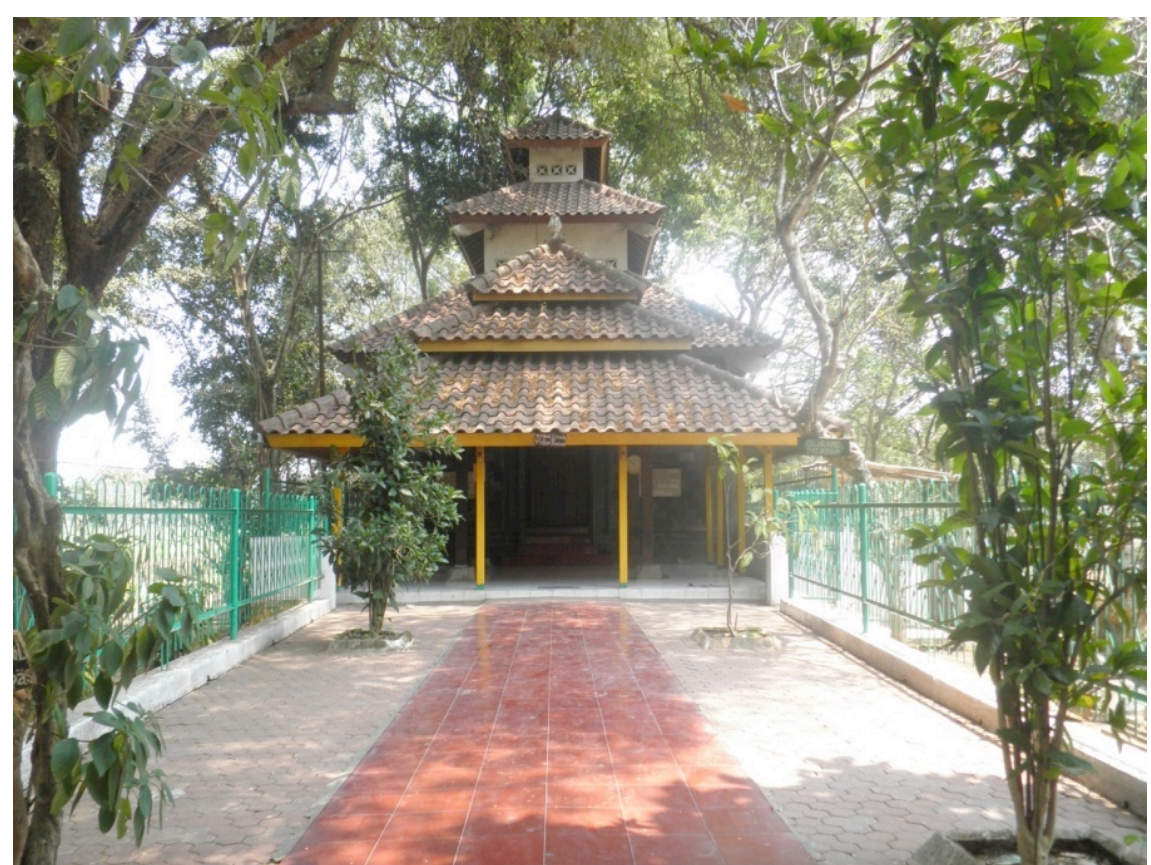

The grave of Eyang (great grandfather) Raden Wijaya at Pendopo Agung site, Trowulan 
Officially opened on 14 February 2004, this structure was built by a Navy Admiral who believes that this is where Raden Wijaya governed the Majapahit Kingdom from 1293 to 1309 and created the kingdom's central hub. Raden Wijaya is revered in Indonesian society today as the founding father of this kingdom. It is also where Gajah Mada (c1290 to c1364) - the 'Elephant General' and a national hero in the republic famously swore an oath that he would not eat any spicy food until his forces had taken over the Nusantara archipelago. This site also has another building in which Great grandfather Raden Wijaya lived as a hermit.

The Majapahit Kingdom, located in East Java, once occupied almost all areas in Nusantarapada from 1293 to 1522. According to the written records, Pararton and Nagarakrtagama, Majapahit Kingdom was established by Raden Wijaya and after his death in 1345 A.D. he was buried in Antapura with Buddhism characteristics and besides Simping with Ciwaistis characteristics. ${ }^{8}$

Although Raden Wijaya was clearly a follower of Hinduism, the Moslem communities surrounding this site revere him. According to interviews with visitors, most of them said that their reason for visiting the great palace was to see the shrine. Others also wanted to search for mysticism around Trowulan. Asking Raden Wijaya believed as the owner of the whole Trowulan as the center for Majapahit Kingdom for mysticism is ritually done by praying or doing meditation on the altar inside the room followed by burning incense or hioh in the same place. According to an interview with the cemetery caretaker, visitors to Great Grand Father Raden Wijaya's shrine come not only from the area near the kingdom, but also from other parts all over Indonesia. This phenomenon illustrates how Indonesians relate their past with spiritual awareness and their belief in their ancestors in the present time by constructing a certain atmosphere as the center for Majapahit Kingdom.

\section{SUMUR (WeLL) UPAS SITE}

Sumur Upas is the name given to the structure made of bricks with tunnels like labyrinth underneath based on the belief that this building was part of the water source for the palace. According to interviews with visitors, the public consider Sumur (Well) Upas to be the place where Raden Wijaya stayed. The site gives them peace, particularly when they have serious problems which can be solved by their visits. Rituals done in Sumur Upas include praying and taking a bath near the well to get Raden Wijaya's blessings to protect them during their life. 


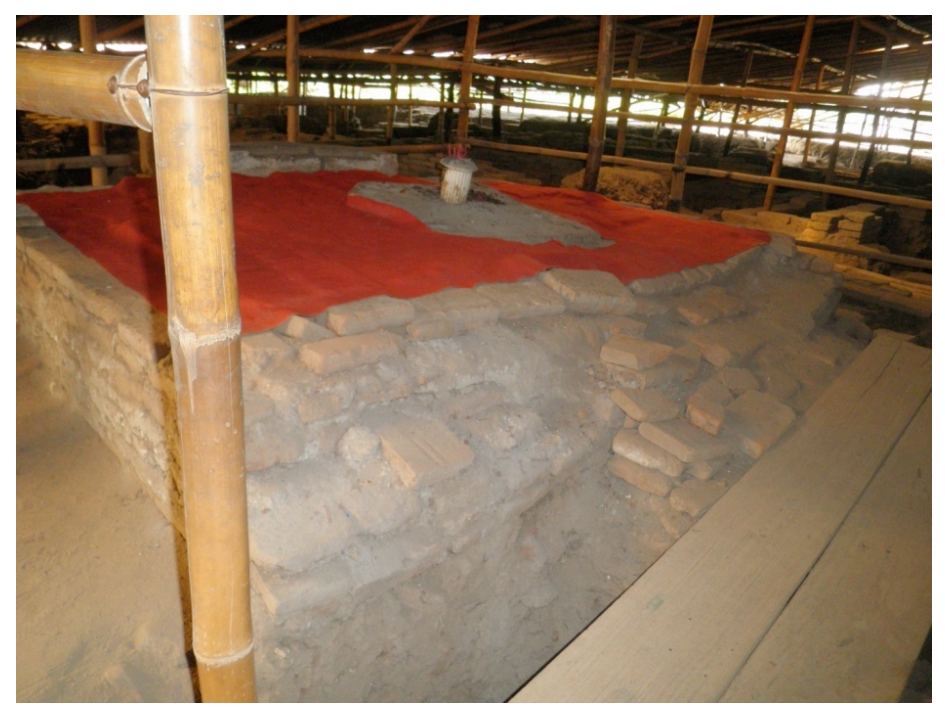

Site for shrine visit at Sumur (Well) Upas

\section{SITI INGGIL}

Indonesians call this site Siti Inggil, from the Javanese word meaning God. It is usually used to name a part of the front yard of a palace where a king had meetings with his people. This building was constructed by the community to mark the burial site of Raden Wijaya and his wife. The building has two tombs and no roof.

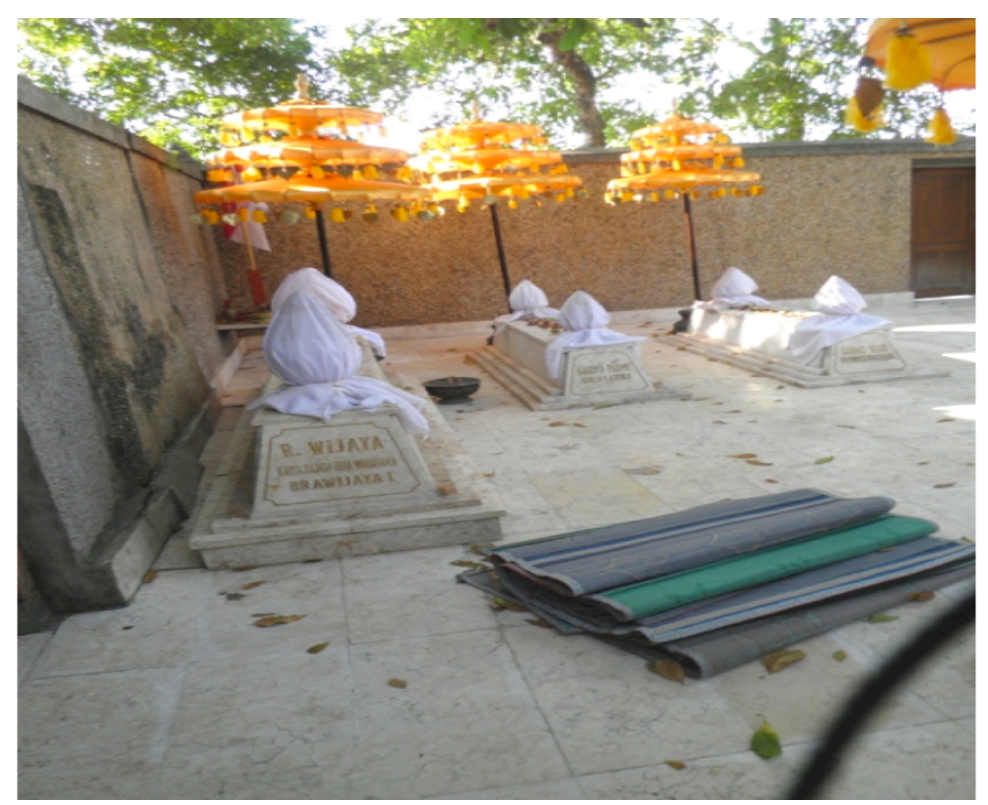

Siti Inggil 
Most Indonesians are convinced that this tomb can give them blessings and they can get mystical power from this tomb by meditating in it. There is also a water source with which people are convinced that visitors can get power or blessings from Raden Wijaya if they drink this water. All these sites are connected to the mythology of Raden Wijaya as the first king of Majapahit Kingdom which the Trowulan community see as being part of their history. Raden Wijaya is resuscitated as Raden Wijaya in Islamic ways, both through the tomb and Islamic prayers.

\section{Public ARChaeology: Is it Needed?}

The most important idea around the definition of public archeology was proposed by Schadla-Hall Team as any hemisphere in archeological activities which have interactions with the public. According to Nick Marriman (2004), this type of archeology involves archeological processes and results in archeology becoming more engaged with public culture which in turn can lead to contestation and dissonance take place. ${ }^{9}$

In America, the term public archeology came into use in 1960 with the new understanding of 'educational archaeology' and 'public interpretation of Archaeology'. These were meant to empower the community and encourage people to critically participate in and evaluate historical and archeological interpretations. Both the community and archaeologists needed to develop understandings of how the past is understood and why such times are still relevant in the present. ${ }^{10}$

All heritages are connected to the present time. Material traces of the past are understood on the basis of the present social needs and requirements and needs. Heritage and archeological interpretations and reconstructions of these should consistently involve community. Jameson further argues that archeology gradually shifts from archeology closed to the public to archeology which makes the community a partner in achieving its goals. These communities included educators, academicians, professionals, ethnic groups and the descendants and local people who are archeologists' partners through dialogues, participation and the sharing of ideas through mutual understanding. ${ }^{11}$ In Indonesia, Public Archeology has been known since the early 2000s and introduced through the undergraduate curriculum at the University of Indonesia and Gajah Mada University. In 2012 a Public Archeology book was published by Archeology Institute in West Kalimantan. Public Archeology, however, has not become a part of the government policy. An effort leading to Public Archeology recently conducted by Integrated 
Archeological Research (Penelitian Arkeologi Terpadu [PATI 2]) in 2012 involved four big universities in Indonesia: the University of Indonesia, Gajah Mada University, Udayana University and Hasanuddin University in doing research regarding Trowulan. In addition, this research invited a number of Vocational High School students and teachers to get involved in this research and they had to actively follow all activities in two weeks in order to informed them about Trowulan as an important site to reveal our past. This was particularly in connection with the Great Majapahit Kingdom in Java due to the fact that archeological data cannot be replaced. We have to work together to conserve these archeological remains. Many brick manufacturing companies which destroy the environment operate around Trowulan. The key target of the research is collaborative activity. How this research message is disseminated to the community through teachers and students has been well managed and it is expected that ideas of preserving this archeological heritage will spread at one level by word of mouth.

\section{CONCLUSION}

The seemingly exclusive authority that archaeologists have held over archeological knowledge and material culture cannot be maintained anymore. The existence of past archeological objects with us at the moment should also give benefits for our future. Single interpretations cannot be maintained anymore; interpretations of the past are multivoice and contested. Present-day traditional archeology must respect the rights of local communities work with their cultural heritage and apply their cultural knowledges. An Alternative Archeology should be given rooms in the houses of history and heritage to interpret our past together with conventional archeological interpretation. Contemporary archeology should be publicly oriented. Archeologists should also widely disseminate their research and interpretations to the public and to involve the public as their partners to reach their research objectives.

\section{Endnotes}

${ }^{1}$ Paul Ashton and Paula Hamilton, History at the Crossroads: Australians and the Past, Halstead Press, Sydney, 2009, pp8-10.

${ }^{2}$ Gary Edson and David Dean, The HandBook for Museum. Routledge, London and New York, 1996, pp5-6.

${ }^{3}$ Colin Renfrew and Paul Bahn, Archaeology: Theories, Method and Practice, Thames and Hudson, London, 2004, pp573.

${ }^{4}$ Laurent Olivier, Laurent, 'The Archaeology of the Contemporary Past', in Victor Buchili and Gavin Lucas (eds), Archaeologies of The Contemporary Past, Routledge, London and New York, 2001, pp186-7. 
${ }^{5}$ Tim Scadla-Hall, 'The comfort of unreason: the importance and relevance of alternative archaeology, in Nick Merriman (ed), Public Archaeology, Routledge, London and New York, 2004, pp255-6.

${ }^{6}$ P. Hiscock, 'The New Age of alternative archaeology of Australia', Archaeology in Oceania, vol 3, pp152-164 <http/ / atalpha.anu.edu.au/web/arc/news/ao.htm>.

${ }^{7}$ Junus Satrio Atmodjo et al, Laporan Kegiatan Kajian Integratif Perlindungan dan Pengembangan 'Situs Kerajaan Majapahit' di Trowulan, Puslitbang Departemen Kebudayaan dan Pariwisata dan Departemen Arkeologi FIB-UI, Jakarta, 2008.

${ }^{8}$ Ribut Darmosoetopo, 'Sejarah Perkembangan Majapahit', dalam 700 Tahun Majapahit (12931993), Suatu Bunga Rampai, (ed) Prof Dr Sartono Kartodirdjo, at Al, Surabaya, Dinas Pariwisata Daerah Propinsi Daerah Tingkat I, Jawa Timur, 1993, pp49-62.

${ }^{9}$ op cit, p5

${ }^{10}$ John H. Jamesson Jnr, 'Public Archaeology in the United states', in Merriman (ed), Public Archaeology, pp21-22.

${ }^{11}$ John H. Jameson Jnr and Sherene Baugher, Past Meets present: Archaeologists Partenering with Museums Curators, Teachers and Community Groups, Springer, New York, 2007, pp4-6. 